\title{
Environmental project management as an element of urban environment component improvement
}

\author{
Łukasz Szałata
}

Wroctaw University of Technology, Environmental Engineering Department, Ecologistic and Environmental Risk Management Division, 50-377 Wrocław, Plan Grunwaldzki 9, e-mail: lukasz.szalata@pwr.edu.pl

\author{
Jerzy Zwoździak \\ Institute of Meteorology and Water Management, National Research Institute, National Air Quality Research Center, \\ 01-673 Warszawa, Podleśna Street 61, e-mail: jerzy.zwozdziak@imgw.pl
}

\begin{abstract}
Proper environmental project management is a significant element in shaping a positive, pro-environmental image of urban agglomerations and adjacent towns. Environmental resource management and protection, as well as spatial planning in accordance with sustainable development principles, are the most important factors in creating a positive image of, and strategies for, cities. An example of a large, innovative environmental project implementation is the Central Sewage Treatment Plant in Kozieglowy, in the agglomeration of Poznan, and its installations and equipment impact assessment studies. Important aspects of the project were mediations, which took place from May 2011, until the end of April 2012.
\end{abstract}

Keywords: sustainable development, environmental projects, environmental management

Submitted 11 February 2015, revised 16 April 2015, accepted 11 May 2015

\section{Introduction}

Environmental management may be defined as a set of practical activities, based on principles of environmental sciences and engineering, which are involved in designing, coordinating and controlling environmental management processes. Processes like shaping the urban environment, as well as using and protecting it, play an important role in economic and social life, including the ecological education of society. Thus, the proper use of environmental management tools is crucial in achieving social acceptance of pro-environmental approaches (Poskrobko 2007).

Rational environmental component management requires the use of multiple methods and techniques aimed at optimizing decision-making. One of the most important tools used in environmental management is SWOT analysis - a structured planning method used to evaluate strengths, weaknesses, opportunities and threats involved in a project. (Obłój 2007; Zwoździak 2007; Olszewska 2008; Jasiński 2011).

An example of a multidimensional, innovative environmental project implementation is the Central Sewage Treatment Plant in Kozieglowy, in the agglomeration of Poznan - assessment of the impact of installations and equipment realized by The Ecologistic and Environmental Risk Management Division of the Environmental Engineering Department, Wroclaw University of Technology.

\section{Selected research project description}

Environmental economics and natural resource management, taking into account sustainable development principles, aim to ensure high ecological, economic and social standards for today's population and for future generations by applying the principle of intra- and intergenerational justice (Rogall 2010, p. 54-82).

The Central Sewage Treatment Plant in Kozieglowy's impact assessment report and its modernization project, prepared by a team of scientists, allowed the implementation of a recovery programme for the whole installation. The Central Sewage Treatment Plant in Kozieglowy is a mechanical biological treatment plant, with increased nutrient removal and sludge treatment, located in the north-eastern part of the City of Poznan, beyond its administrative borders.

The Plant is capable of receiving $200000 \mathrm{~m}^{3}$ of sewage a day, a figure that can rise to up to $260000 \mathrm{~m}^{3}$ during heavy rainfall periods. In the second half of 2011, the average daily amount of sewage received by the Plant was approximately $105000 \mathrm{~m}^{3}$. Effluents after treatment processes are received by the Warta River. Currently the population equivalent for the Plant is $\mathrm{PE}=1000000$ and it is predicted this will rise to $\mathrm{PE}=1200000$ (Materiały COŚ Koziegłowy). Population equivalent (PE) is the number that expresses the ratio between the sum of the pollution load produced during 24 hours by industrial facilities 
and the individual pollution load in household sewage produced by one person over the same period.

The research was divided into four thematic sections, including specific research methodology for each issue undertaken. An odour impact assessment of the Central Sewage Treatment Plant, as well as an ambient air quality assessment was carried out. The research methodology was supplemented by health surveys (consisting of questions about state of health). The questionnaires were given to a group of people living in close proximity to the Plant, in Kozieglowy and in a part of Czerwonak. Also, mediations were carried out throughout the whole research process.

The obtained results allowed for the design of a series of modernization projects for the Plant, including shelterbelts and windbreak planting, a change of sewage storage process, biofiltration technology optimization and the implementation of more efficient technological line element encapsulation.

\section{Research methodology}

\subsection{Central Sewage Treatment Plant odour impact as- sessment}

A group of experts were selected in accordance with the PN-EN 13725 standard Air quality. Determination of odour concentration by dynamic olfacto-metry, and a reference sample, n-butanol in nitrogen, was used. The experts were subjected to regular tests, with the use of a 4-position olfactometer TO8. According to the standard, the tests were conducted in a silent, isolated room, with stable light and temperature conditions.

The location of the study area encompassed Kozieglowy and a part of Czerwonak, both parts of Czerwonak municipality, as they are areas located closest to the Plant and are thus most exposed to odour nuisance. The majority of recorded complaints regarding odour nuisance came from these areas.

Field research was carried out in accordance with German VDI 3940 standards. The study area was called the "measurement area" and consisted of "measurement points". These points were located in a "measurement grid", which consisted of 104 points, spaced every $200 \mathrm{~m}$.

The obtained research results allowed for the determination of the frequency of the occurrence of a particular odour, expressed in "odour hours", which means an odour was sensed longer than through $10 \%$ of a measurement time (more than six times). Additionally, the intensity of odours emitted from the plant was measured, using the scale of 1 to 6 , where 1 - very weak, and 6 - extremely strong odour. In order to maximize the reliability of the measurements, they were performed at least

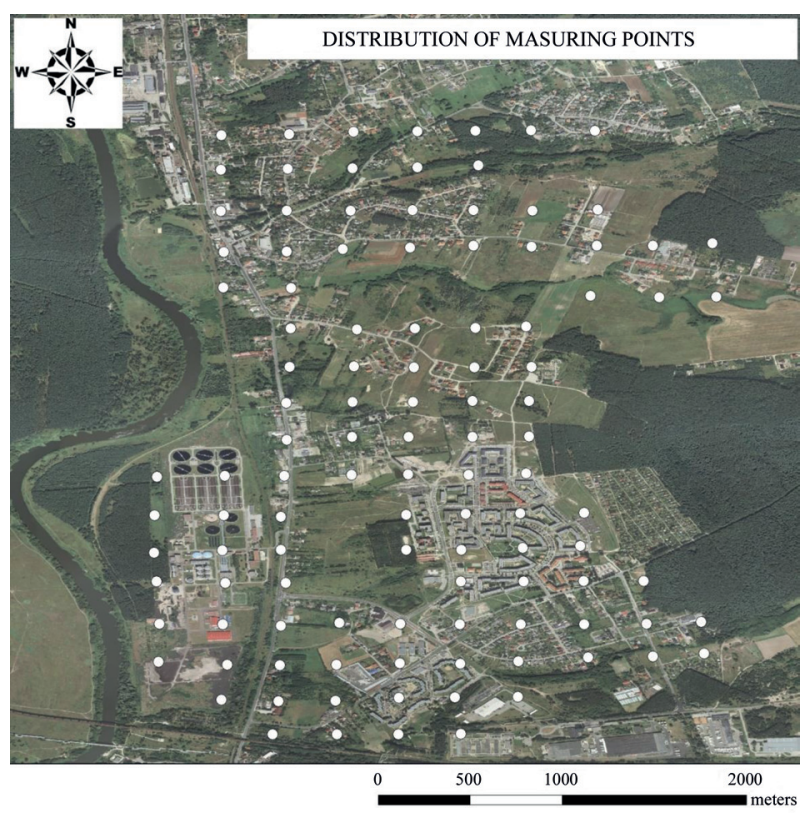

Fig. 1. Measurement grid designated for field research of odour emission and nuisance assessment (prepared by the Institute of Environmental Protection Engineering, Technical University of Wrocław)

three times at a given sampling point, at different times of the day (morning, day, evening, night), by different evaluators, and the points, date and time of measurements were assigned randomly to the evaluators. Measuring points formed squares, which enabled the evaluation of the frequency of the occurrence of particular odours in the studied area.

\subsection{Ambient air quality assessment}

In order to identify the potential impact of the plant on the quality of ambient air, the amount of the same type of microorganisms that occur in the treated sewage was measured in the ambient air. Also, the amount of microorganisms mentioned above was determined in four averaged samples of wastewater, representing sewage at four different stages of the treatment process:

- averaged sewage sample from all primary clarifiers operating on the day of sample collection;

- averaged sewage sample from all aerated bioreactors operating on the day of sample collection;

- averaged sewage sample from all non-aerated bioreactors operating on the day of sample collection,

- averaged sewage sample from all secondary clarifiers operating on the day of sample collection.

From each sewage sample, a series of dilutions was prepared and inoculation using the streak plate method was then performed. The total number of psychrophilic and mesophilic bacteria and fungi was determined on the basis of pour plate method results. 
The number of airborne microorganisms was determined by the sedimentation method, accor-ding to PN89/Z-04111/01, PN-89/Z-04111/02, PN-89/Z-04111/03 and $\mathrm{PN}-89 / \mathrm{Z}-04111 / 08$ standards. Air sampling points were placed in the wind plume, taking into account terrain obstacles. The number of psychrophilic bacteria and fungi in the air volume unit was also determined at points where olfactory measurements were performed.

Petri dishes (agar plates) with a diameter of $9 \mathrm{~cm}$ were exposed to free falling microorganisms - for $30 \mathrm{~min}$. and at a height of $130 \mathrm{~cm}$ above the ground. The petri dishes containing growth medium were then incubated at appropriate temperatures. After this incubation, the colonies growing on plates were counted. The number of colony forming units (cfu) per air volume unit was calculated with the Omelianski formula (with Gogoberidze modification).

The number of cfu of mesophilic bacteria, actinomycetes, Pseudomonas fluorescens, $\alpha$ - and $\beta$-hemolytic staphylococci and fungi was the basis for determining the microbial air contamination degree at a given point, in accordance with criteria specified in PN-89/Z-04111/02 and PN-89/Z-04111/03 standards.

\subsection{State of health assessment}

State of health assessment of residents of Kozieglowy and part of Czerwonak was carried out on the basis of a health survey, prepared by Professor Krystyna Pawlas from the Department of Hygiene at the Medical University of Wroclaw. The survey consisted of questions related to a subjective health eva-luation of survey participants. Three groups were set up on the basis of analysis of the surveys, and from these, persons selected for the study were designated.

The participants were Central Sewage Treatment Plant employees, and also persons randomly chosen from the two populations. The first population consisted of people living in close proximity to the plant, the second one was a reference group - people living at a considerable distance from the plant. These two groups included preschool children and schoolchildren, and also adults. The selection of the population subjected to the test was carried out in accordance with developed methodology.

In order to meet the principles of Best Epidemiological Practice, the population subjected to the test was chosen randomly. The study included two groups: children aged 3-10 and adults aged 20-65.

The study included people living in every tenth apartment, according to the address list of the area covered by the impact of the plant, and the control group, consisting of people living at a considerable distance from the plant. Both groups were resident in the Czerwonak municipality.

According to the principles of sample size evaluation for categorial variables, taking into account the age structure of Kozieglowy residents (approx. 11000 people) and the residents of the part of Czerwonak municipality living outside the range of impact of the plant (approx. 5000 people), less than 5\% were children aged 5-10 and about $80 \%$ were adults.

The third group consisted of people who were able to fill in the survey at points prepared particularly for this purpose. Information on the possibility of voluntary survey completion was distributed in advance.

Health research began on October 17 and the interviewers completed their work in December 2011.

Public consultation with the local community and interested parties was also organized. A meeting, named „Health Days”, was organized to present previous research results, provide health consultation with specialists from the Medical University of Wrocław and to allow people not covered by the study to complete the health survey.

\subsection{Social mediation}

Taking into account the complex nature of the Central Sewage Treatment Plant impact assessment, the social mediation process was an extremely important element of the research team's work.

Numerous complaints by residents, and meetings with interested parties, confirmed our belief that the role of social mediators is crucial at the stage of building and strengthening a positive image of, and gaining social acceptance for, modernization projects.

An important element of social mediation with interested parties is the constant exchange of information at every stage of the process. Local societies are becoming more aware of their rights and interests (Folta 2011; Federczyk 2013; Gmurzyńska, Morek 2014), and the more a social community gets organized, the more it increases its awareness of its inte-rests and, consequently, there is greater likelihood of conflict involving many parties.

These conflicts, and lack of procedures and mechanisms for solving them, may bring with them specific social, economic and environmental costs. Knowledge of methods for settling disputes and achieving social acceptance for proposed solutions is highly valuable.

These disputes frequently address key issues of a local nature, and often the interests of individuals or local community groups are contrary to the interests of a larger community. 
Due to the complexity of the conflict between the Central Sewage Treatment Plant and the local community, the issue was addressed in a comprehensive manner, and was based on experience, conflict recognition and the use of social models in order to achieve social consensus.

Therefore, the local communities and interested parties were kept informed of the results and progress of the research. Knowledge of environmental components distributed among the local community positively affected an increase of environmental awareness of the community and interested parties, and this, in turn, noticeably reduced complaints related to the work of the Sewage Treatment Plant.

\section{Media cooperation}

Media cooperation plays an important role in the management and coordination of environmental research projects. It is important to provide the local community with access to information on research results and progress, as well as with the results of social mediation. Our research team from The Ecologistic and Environmental Risk Management Division of the Environmental Engineering Department, Wrocław University of Technology took care to ensure constant access to information regarding the realization of the project.

Press conferences were a key source of information exchange. During them, interested parties, including local communities and representatives of residents of Czerwonak municipality, such as the "Live Normally" Association, regional press and television, had the opportunity to participate in discussions and receive information on the scope of the project.

Experts from the research team were interviewed during press conferences, as well as during meetings with local communities and on "Health Days". On top of this, they provided information on the course of work through the media and with various information tools.

In terms of social mediation, tools such as bilateral negotiation were introduced in order to achieve preliminary agreement and social acceptance of particular parts of the modernization project. One of the most important results of the mediation process was the involvement of all stakeholders in the course of the work and the team meeting between the Mayor of the City of Poznan and the experts on environmental impact studies who led the Central Sewage Treatment Plant in the Kozieglowy modernization project.

Other important events were "Health Days", organized to present research results related to the health surveys, provide health consultation with specialists from the Med- ical University of Wroclaw and to allow people not covered by the study to complete the health survey.

It should be noted that this type of research is a novelty in the field of environmental project management and the shaping of a pro-environmental image of urban agglomerations. Further implementation of the Central Sewage Treatment Plant in Kozieglowy modernization project will provide a positive ecological effect and obtain a socially acceptable state of the environment, in accordance with European Union legal standards for the protection of the environment.

\section{Environmental management mechanisms using the example of air quality assessment}

Under current Polish regulations, there are two air quality management systems. The first relates to air quality monitoring systems and the second aims to protect air quality by reducing and preventing the emission of pollutants. Each system can be divided into subsystems, e.g. air quality management in emergency systems, air quality management at the investment planning stage, etc. Each management system is based on actual data, knowledge and information flow.

Environmental management is carried out by central and local governments and institutions and entities using the environment. Each system has its own tools, instruments and management measures. Measures are informative, organizational, technical and technological.

These tools help us understand the essence of environmental management and include all activities associated with the identification of problems, and the development of strategies and solutions to solve them. Instruments can directly and indirectly affect the management object (control standards and various types of documents). These are divided into:

- direct regulation instruments - legal and administrative,

- indirect regulation instruments - complementary to direct regulation instruments.

In Poland, the tools and instruments are often used interchangeably.

\section{Summary and conclusions}

Implementation of large, multidimensional environmental projects needs the involvement of experts in the field of environmental components protection as well as constant consultation and dialogue with all interested parties; this is particularly the case in projects that have a large social impact. 
Table 1. Categories of instruments used in environmental policy (own work)

\begin{tabular}{|c|c|}
\hline addressed instruments & specialized instruments \\
\hline \multirow[t]{5}{*}{ legal and administrative regulations } & prescriptive standards \\
\hline & performance standards \\
\hline & prohibitions and restrictions \\
\hline & certification and permits \\
\hline & other regulations \\
\hline \multirow[t]{4}{*}{ financial and market mechanisms } & emissions trading \\
\hline & financial incentives \\
\hline & fees and penalties \\
\hline & other mechanisms (subsidies, taxes, tax relief) \\
\hline \multicolumn{2}{|l|}{ negotiated agreements } \\
\hline \multirow[t]{2}{*}{ voluntary management and social corporate responsibility } & voluntary agreements \\
\hline & "order in our own backyard" \\
\hline \multirow[t]{4}{*}{ support programmes } & information flow \\
\hline & promotion and raising of social awareness \\
\hline & codes of conduct and best practice \\
\hline & building potential \\
\hline
\end{tabular}

As a result of the conducted work, a recovery programme was prepared and implemented. The programme was developed on the basis of annual studies, conducted by a team of experts, and used reports on particular stages of the project.

The report contained the methodology and discussion of the obtained research results. The sewage treatment plant working technology was described; the odour and microbiological impact assessment, combined with model calculations and spatial visualizations were carried out; and a comprehensive analysis of the state of health survey results pertaining to people living in close proximity to the Plant in Czerwonak municipality was also performed. The report also described the whole social mediation process.

The key recommendations arising from the research results and discussion were: the elimination, or at least significant reduction, of microorganisms and odour emissions to the ambient air from treated sewage and the bioaerosol forming over its surface; this should be achieved through investment related to bioreactors and primary settler en-

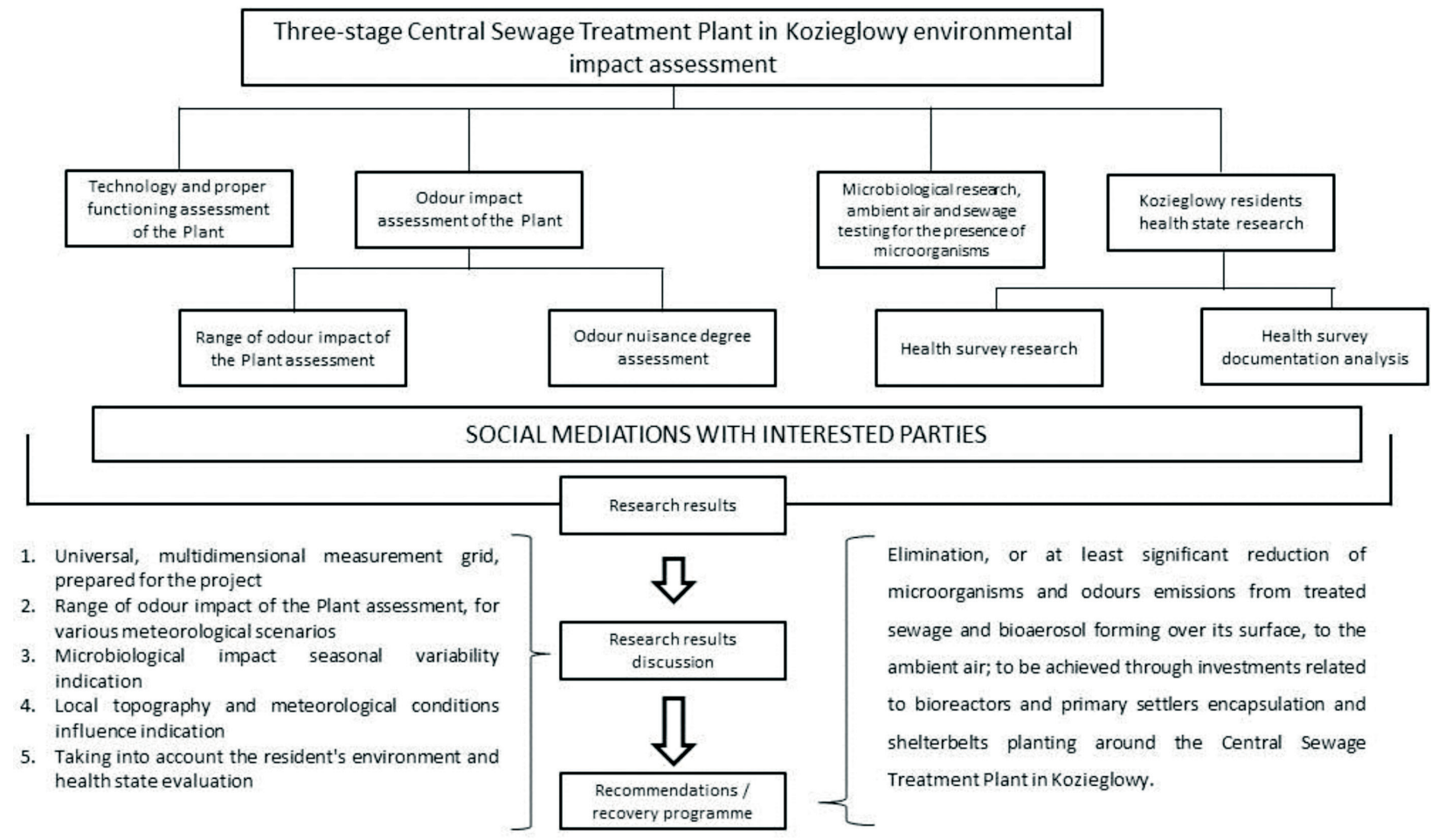

Fig. 2. Diagram describing research project stages 
capsulation and shelterbelt planting around the Central Sewage Treatment Plant.

It is therefore necessary to optimize technological processes and seek solutions for limiting the impact of a selected plant or installation on human health and individual environmental components.

The combination of all elements of the project and a proper environmental management strategy are crucial for the project's successful implementation process, which is based on effective project management methodology (Wysocki 2013), and results in the intended purposes being achieved. It is also important to take into account the principles of neoclassical economics, in terms of analysis of dependencies between environmental pollution and exploitation and economic growth (Fiedor 2002).

Achieving a positive ecological, economic and social effect will enable the fulfillment of the objectives of sustainable development (Kryński et al. 2013), which include the socialization of decision-making processes and the sociocultural dimension of future society. The three main objectives - ecology, economy and society - derive from the philosophy of modern urban agglomeration management - as a balanced set of orders such as natural, social \& demographic and economic order (acceptability of undertaken activities) as well as spatial order, in terms of spatial development (intelligent environmental solutions).

It is necessary to realize environmental investments and pro-environmental projects in accordance with sustainable development principles and the gaining of social acceptance for the measures taken. A consequence, and positive aspect, of these activities will be reflected in the greater commitment of citizens to the future of the cities they live in, as well as their identification and engagement with pro-environmental programmes.

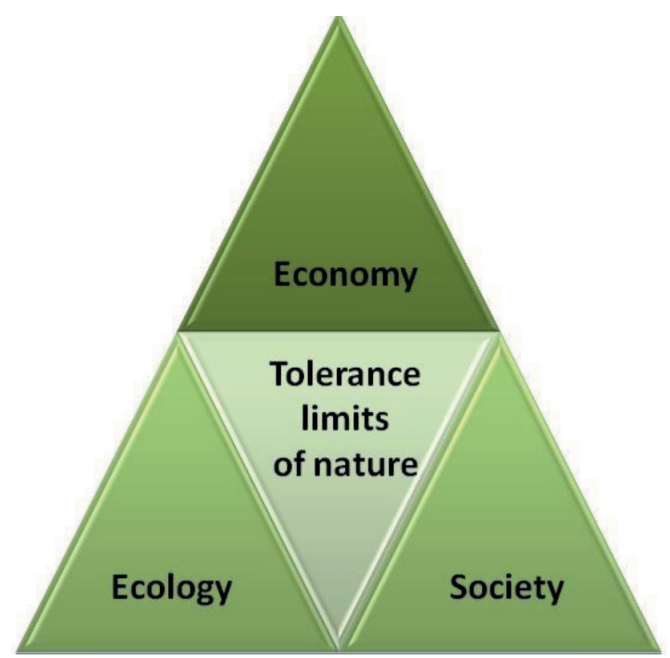

Fig. 3. Triangle of sustainable development objectives (own work)
Bibliography

Berbeka K., 2013, Water intake fees as an instrument for sustainable water resources management, Meteorology Hydrology and Water Management - Research and Operational Applications, 1 (1), 3-8

Fiedor B. (ed.), 2002, Fundamentals of environmental economics and natural resources (in Polish), C.H. Beck, Warszawa 2002, 488 pp.

Folta M., 2011, Mediation and negotiation from within: $16 \mathrm{vec}-$ tors for creative imagination trialogue (in Polish), FOLTA, Wrocław

Federczyk W., 2013, Mediation in judicial and administrative proceedings (in Polish), Wolters Kluwer Polska, Warszawa, $311 \mathrm{pp}$.

Gmurzyńska E., Morek R., 2014, Mediation - theory and practice (in Polish), $2^{\text {nd }}$ edition, Wolters Kluwert Polska, Warszawa, $492 \mathrm{pp}$.

Jasiński Z., 2011, Fundamentals of operational management (in Polish), $2^{\text {nd }}$ edition, Oficyna Ekonomiczna - Wolters Kluwert, Kraków

Kryk B. (ed.), 2012, Environmental management (in Polish), Uniwersytet Szczeciński, Szczecin, 367 pp.

Kryński A., Kramer M., Caekelbergh A. (eds.), 2013, Integrated environmental management (in Polish), Wolters Kluwer Poland, Warszawa, 932 pp.

Majewski W., 2013, Sustainable development of the lower Vistula, Meteorology Hydrology and Water Management - Research and Operational Applications, 1 (1), 33-37

Obłój K., 2007, The organization strategy - in search of durable competitive advantage (in Polish), $2^{\text {nd }}$ edition, Polskie Wydawnictwo Ekonomiczne, Warszawa, 484 pp.

Olszewska B. (ed.), 2008, Strategic management - company on the threshold of the XXI century (in Polish), Wydawnictwo Uniwersytetu Ekonomicznego we Wrocławiu, Wrocław, 245 pp.

Poskrobko B., 2007, Environmental management (in Polish), Polskie Wydawnictwo Ekonomiczne, Warszawa, 328 pp.

Rogall H., 2010, Sustainable development economics - theory and practice (in Polish), Wydawnictwo Zysk i S-ka, Poznań, $578 \mathrm{pp}$.

Wysocki R.K, Mcgary R., 2003, Effective Project Management: Traditional, Adaptive, Extreme (in Polish), $3^{\text {rd }}$ edition, Helion, Gliwice, $536 \mathrm{pp}$.

Wysocki R.K, 2013, Effective project management - traditional, variable, extreme (in Polish), $6^{\text {th }}$ edition, Helion, Gliwice, $832 \mathrm{pp}$.

Zwoździak J., 2007, SWOT: Heuristic analytical method, Foresight Polska 2020 National Programme - Technologies for environmental protection (in Polish), Rzeszów 